\title{
Study on Talent Training of Architectural Decorative Art Design of School-enterprise Integration
}

\author{
Laiquan LIU, Ruie ZHANG, Jiwei WEN*', Shixiong DING, Zhuoran LI, Yiwei XUE \\ Hainan College of Software Technology, Qionghai, Hainan, China
}

ABSTRACT: The article takes the major of architectural decorative art design in a vocational education school in Hainan as the illustration to discuss the professional construction background, location of talent training, and thinking of talent training, and train the professional talents with the thinking of schoolenterprise integration. The article proposes four steps of school-enterprise integration, and uses "schoolenterprise" cooperation to break the ice of "school-enterprise cooperation". Finally, we will use the form of school-enterprise integration to achieve the goals of alternation of work and study and work-shift of teachers, and deeply push production-study-research forward.

KEYWORD: school-enterprise integration; school-enterprise cooperation; architectural decorative art design; talent training

\section{BACKGROUND OF MAJOR SETUP}

In recent years, the construction industry of Hainan province are booming with the rise of the national construction industry, the added value of construction industry of GDP of Hainan province is gradually increasing year by year, as shown in the table of "the added value of construction industry of Hainan province of GDP of Hainan province during 2005 to 2013". While the architectural decoration industry as one of the three pillar industries of construction industry, is also growing rapidly as a sunrise industry with the development of construction industry.

Table 1 The added value of construction industry of Hainan province of GDP of Hainan province during 2005 to 2013 [1]

\begin{tabular}{|c|c|c|c|}
\hline Date & $\begin{array}{c}\text { GDP of Hainan province } \\
\text { (billion) }\end{array}$ & $\begin{array}{c}\text { Added value of construction of hainan } \\
\text { province (billion) }\end{array}$ & $\begin{array}{c}\text { The added value of construction of provincial } \\
\text { GDP of Hainan province }\end{array}$ \\
\hline 2013 & 3146.46 & 320.18 & $10.18 \%$ \\
\hline 2012 & 2855.54 & 283.32 & $9.92 \%$ \\
\hline 2011 & 2522.66 & 239.46 & $9.49 \%$ \\
\hline 2010 & 2064.5 & 185.79 & $8.03 \%$ \\
\hline 2009 & 1654.21 & 142.8 & $7.63 \%$ \\
\hline 2008 & 1503.06 & 114.66 & $6.85 \%$ \\
\hline 2007 & 1254.17 & 85.89 & $6.60 \%$ \\
\hline 2006 & 1065.67 & 70.31 & $6.96 \%$ \\
\hline 2005 & 918.75 & 63.91 & \\
\hline
\end{tabular}

*Data source: NBS

Promulgated by the state council on January 4, 2010 , "The state council's several opinions on promoting the development of the construction of Hainan international tourism island [2]", the construction of Hainan international tourism island is risen as the national development strategy. Since the construction of Hainan international tourism island officially opened, the architectural decoration industry in Hainan is also get a rapid development, and the growth rate of the output value from architectural decoration industry is far higher than the growth rate of GDP of the same period in Hainan province. The rise of the architectural decoration industry thus acquired a large number of 
professional talents, so Hainan software vocational education school set the major of architectural decorative art design to meet this requirement, to provide design talents of indoor and outdoor decoration design in Hainan province.

\section{THE ORIENTATION OF TALENTS TRAINING}

Based on the principle of serving provincial economy, by extensive research, the major of architectural decorative art design will provide high quality technical special artistic talents who received basic theory and method of indoor and outdoor the architectural decorative art design training and can skilled in hand-painted performance, engineering drawing, computer effect, budget, and construction management for the stations as effectiveness performance, CAD drawing, decoration designer, interior designer, landscape designer, etc. of Interior design company, Interior decoration company, Garden design company, Real estate development company, architectural design and research institute and so on.

\section{THE IDEA OF TALENTS TRAINING}

Establish the scientific and distinctive talent training mode and practical teaching orientation is the important premise of talent training. According to the development trend of decoration industry and disciplinary development characteristics of school, the talent training of the major of architectural decorative art design should put strengthen the foundation, emphasize the ability, pay attention to practice, work-integrated learning for station, "as the goal, to develop a solid professional foundation for fundamental, train practical ability of the student as the core, to aim at the employment as the goal, adhere to the combination of classroom teaching and practice, the principle of combining practical training inside campus and practice outside campus, emphasize the combination of learning with working to apply the practical teaching throughout the whole teaching process.

\subsection{Promote talent training mode of school- enterprise integration, section by section training and basic\&example\&item.}

To promote talent training mode of school-enterprise integration, section by section training and basic \& example \& item. That is through the win-win mechanism established by cooperation of universityenterprise, based on the actual working process, to carry out the training in accordance with four steps of "preparation, pre-design phase, latter design phase, construction organization", after the end of each phase, at least arrange for an actual combat training of project, all phases are finished, conduct a comprehensive actual combat training, so as to ensure to provide qualified design talents. Courses system of decoration art major will make the talent training mode be modular reflected, combined and optimized the courses, focus on professional basis, ability training, hands-on practice, station reproduction, truly achieve the goal of workintegrated learning. So that the students can be competent the requirement of the post given by society, to widen the students' employment and improve the students' employment ability on the basis of professional foundation and practice operation ability [3].

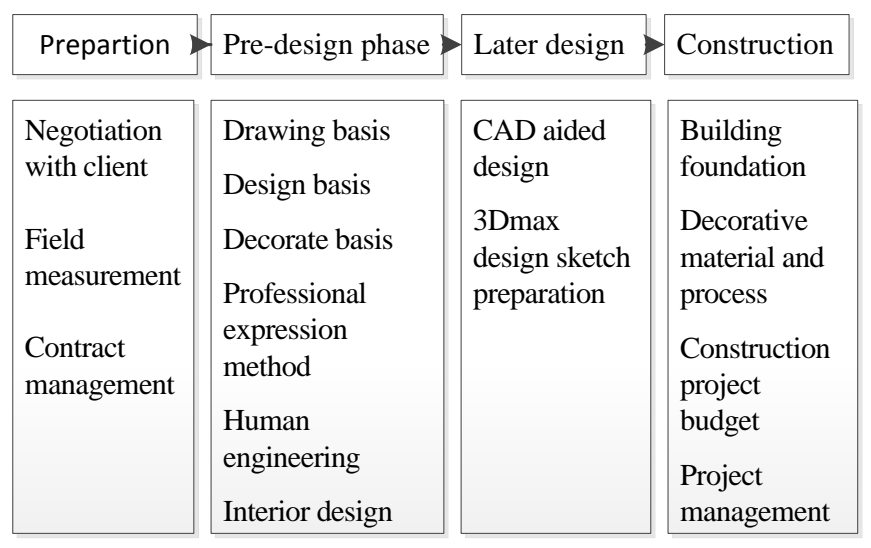

Fig. Block diagram of professional course system of decoration art design

\subsection{Construct diversified practical teaching system}

Construct diversified practical teaching system on the basis of the practice teaching, to improve project practical teaching, integrated comprehensive practice teaching system:

- Basic practice teaching mainly includes course experiment, course training and centralized training, so as to strengthen the student's basic professional skill, divergent thinking and personality cultivation.

- Project practice teaching mainly includes irregular participating in commercial projects. Based on the platform created by schoolenterprise integration, to take various kinds of architectural decoration design projects, to improve the design level of the students by participating in commercial projects with the leading of teachers.

- Comprehensive practice teaching mainly includes pre-service training, substituted post exercitation, etc. which arranges students to participate in each step of actual project of enterprise, conducts overall planning, design and preparation and construction management, and improve their practice and innovation ability. 
Through systematic and comprehensive practice teaching, causes the student to obtain the system of vocational skills training, combining theory with practice, promote the support of theory and practice, and improve the students ability to solve practical problems.

\subsection{Rooted in local culture of Hainan, construct the course system with southeast Asia decorative style}

To serve the regional economic culture, it is highlighting the Southeast Asia decorative style in this major course teaching. Southeast Asia style of interior design thinking for its natural beauty from the tropical rain forest and rich national features being popular in the world, especially welcome in Hainan island and the pearl river delta region with the similar climate, so that the design style of Southeast Asia become more popular.

Major of decoration art design provides training for decoration design talents who will meet the requirements of region decoration culture. Through the combination of the modern space design theory, decoration theory with Southeast Asia decorative style, who will create a decorative style with distinct regional feature. This regional decorative style and other design style and genre are unified, which improve the comprehensive design level of students.

\subsection{Practice the system of double certificate education-"combination of course and certificate"}

Employment as the guidance, based on the requirement of professional station ability, deeply integrated vocational skills certification requirements and content of courses, adhere to double certificate education of vocational qualification certificate and graduation certificate, so as to improve the competitiveness of employment.

\section{TRAINING METHOD OF INTEGRATION OF UNIVERSITY AND ENTERPRISE}

\subsection{Four steps to realize integration of university and enterprise}

Through analysis and research of interests mechanism of double subjects of universityenterprise cooperation, with the aid of the gathered advantage of Hainan software park, by "university joints into the ecological software park, and invites decoration design enterprises, establish the practical training of school according to the production line, so as to build school-run enterprises", to realize " school in the park", " unification of universityenterprise "through the cooperation of university enterprise "and" university \& enterprise - enterprise", thus realize the integration of universityenterprise.

\subsubsection{University joints into the ecological software park}

University jointed in Hainan ecological software park in 2009, purchase the industry-universityresearch building, realizing the zero distance of physical location of park \& industry \& enterprise, and then achieving the connection of major and industry. After joint in the park, the university is no longer an independent institution of higher learning, but being the neighbor with enterprise in the same park, and under the leadership of the government and the park, to seek the development of industry together.

\subsubsection{Build school-run enterprises}

Relying on school-run enterprises established by university, settled in industry-university-research building, and then put into operation, and then realize the cooperation of university-enterprise through peer cooperation of enterprise -enterprise.

\subsubsection{Establish the practical training of school according to the production line}

For better connection of teaching process and production process, first of all to make learning environment in line with working environment, that is to establish the practical training of school according to the production line.

\subsubsection{Invite decoration design enterprises}

For industry-university-research base and school training, both can't separate from the support of the enterprise, even cannot depart from the productive projects of the enterprise. Thus, university actively carry out the policy of " Invite decoration design enterprises ", to invite design department of wellknown enterprises in industry to settle in industryuniversity-research base and school training office for the connection of teaching process and the production process, promote the teachers and students to participate in commercial project of enterprise, and then carry out further training of industry-university-research.

\subsection{Use the form of school-enterprise integration to achieve the goal of alternation of work and study}

\subsubsection{Alternation of work and study}

Under the mode of school-enterprise integration, we achieve the actual alternation of work and study in the training process of student. Students can participate in school-run enterprise or introduced enterprise to joint the actual combat of commercial 
item after receiving project training on training base in campus. In the process of joining the actual combat, with continuously complement of other relevant theoretical knowledge, so as to achieve the goals of alternation of work and study [4].

\subsubsection{Join commercial item with salary}

Students to participate in school-run enterprises commercial projects in the process of actual combat, school-run enterprise profits part sent to all students, realize the distribution according to work, to inspire the students' learning enthusiasm. Students to introduce enterprises to participate in the project of actual combat, can also be based on what has created to get the corresponding economic subsidies.

\subsection{Use the form of school-enterprise integration to achieve the goal of work-shift of teachers.}

School-run enterprise full-time employing skilled experts in industry, and a professional leader served as general manager of school-run enterprise. The cooperative enterprise boasts an excellent team that consists of domestic and foreign well-known industry elites. Using high quality resources from enterprises, we will use a work-shift way for professional teachers to join in the enterprise and participate in the project, which is alternate in teaching in campus and participating project in enterprise, who acts as a lecturer in school, and as an employee in enterprise. Using the work-shift way for professional teachers, effectively improve the professional quality of teachers, also lay a solid foundation for the cultivation of the students.

\subsection{Use the form of school-enterprise integration to deeply push production-study-research forward}

Under the mode of integration of universityenterprise, university established a deep relations with enterprise through school-run enterprise. To serve the regional economic development, provide help for Hainan international tourism island construction, and promote Hainan local culture, to carry out industry-university-research cooperation together. Such as the study of the Southeast Asia style of decoration, to research decoration material available for Hainan regional style, and provide technical support of training, design and construction for small decoration enterprise.

\section{REFERENCE}

[1] National Bureau of Statistics. Provincial annual data[DB/OL]. [2014-11-11].

[2] [DB/OL].http://www.gov.cn/zwgk/201001/04/content 1502531.htm

[3] State Department. The state council's several opinions on promoting the development of the construction of Hainan international tourism island

[4] Weiping Shi. Comparison of vocational and technical education. Shanghai: East China Normal University Press. 2001

[5] Runhui Lin. School-enterprise cooperation-method, strategy and practice of vocational college. Beijing: Tsinghua University Press, 2012 